\title{
EFFECT OF PEPPERMINT (MENTHA PIPERITA) POWDER ON PERFORMANCE, GUT MORPHOLOGY AND IMMUNE ORGANS RESPONSE OF COCCIDIOSIS INFECTED BROILERS
}

\section{S. M. Hussein \\ Lecturer}

Dept. Anim. Prod., Coll. Agric. Eng. Sci., University of Duhok, Duhok, Iraq

Corresponding author: Sherzad.hussein@uod.ac

\section{ABSTRACT}

This experiment was performed to find out the effect of peppermint on the performance, gut morphology and immune organs of coccidiosis challenged broilers. A feeding trail was conducted on 320-day-old Ross 308 chicks allocated to 32 floor pens in a $2 \times 4$ factorial arrangement. The studied factors were: challenge (Negative or Positive) and feed additive (Control, Peppermint and). On day 8 of age, birds in challenged groups were orally inoculated with Eimeria tenella. On day 35 Eimeria decreased weight $(P<.0001)$ gain and deteriorated feed conversion ratio $(P<0.05)$. On 24 and 35 days of age, broilers given salinomycin and peppermint had improved weight gain and feed conversion ratio compared to controls $(P<\mathbf{0 . 0 5})$. Significant challenge $\times$ additive interactions were observed for weight gain, feed intake, feed conversion ratio villus height, crypt depth and apparent villus surface area on d 24 and $\mathrm{d} 35$. Challenged broilers in salinomycin and peppermint groups had significantly increased villus height and villus height/crypt depth and decreased crypt depth compared to positive control. Challenged birds exhibited significantly longer, wider and larger area of bursa of Fabricius lymphoid follicles compared to non-challenged birds. These results illustrated that, peppermint has high protective efficacy against declining in the performance and gut health of coccidiosis infected broilers.

Key words: peppermint, broiler, performance, gut morphology, coccidiosis

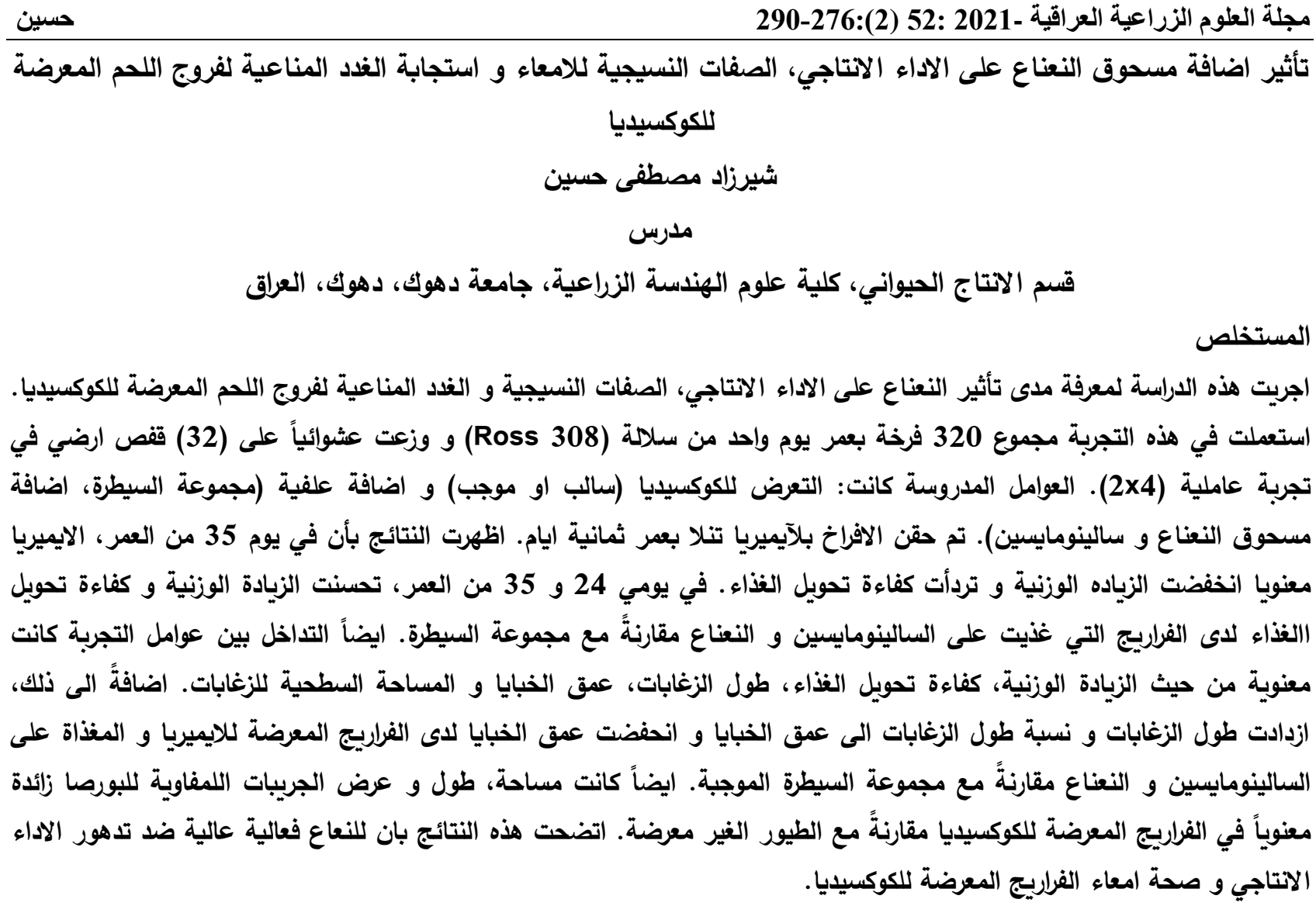

كلمات مفتاحية: النعناع، فروج اللحم، الاداء الاتتاجي، الصفات النسيجي للامعاء، كوكسيديا. 


\section{INTRODUCTION}

Coccidiosis (Eimeria spp.) is one of the several contagious disease caused by protozoan parasite of the genus Eimeria (39). It possess a universal importance in poultry production field. The disease may infect all species of poultry in any system of rearing. Globally, the poultry industry has spent a huge amount of money to prevent and treat this infectious disease (36). Numerous species of Eimeria have been documented and each of them infects a particular part of birds' intestine. The parasite is multiplying in the intestine of birds causing tissue damage and interruption of gut integrity, resulting in declined feed and water intake and nutrient absorption, increased intestinal passage time, villus atrophy, dehydration, blood loss, and rise sensibility to other diseases (41). Coccidia has also caused a high economic lose in poultry sector through decreasing of birds' body weight gain, poor feed conversion ratio, increasing of morbidity and mortality rate among them, and high medications cost (12). Various pathogens such as Clostridium perfringens might be colonized in the intestine which will lead to necrotic enteritis as a result of changes in its function and induced damage of its tissues (24). Caecal coccidiosis caused by Eimeria tenella may contributes to an increased severity of blackhead disease in chickens (25). Since 1940s, chemotherapeutic anticoccidials and vaccines have been used as major components in controlling of coccidiosis (11). These compounds, are efficient disease controllers if used in carefully designed prophylactic treatment programs. However, the in-feed using of anticoccidials has been banned universally due to inevitable development of drug resistance to chemical types of anticoccidials by Eimeria strains as well as the public concern over the use of chemical anticcocidials in the diet of food animals (1). This has forced the researchers to re-examine alternative type of coccidial control. Mannanoligosaccharide (MOS), n-3 polyunsaturated fatty acids, yeast cell wall extract, medicinal plants and natural herbs and their essential oils all have potential coccidiostat activity and suppressing ability of chickens' and turkeys' intestinal mucosa pathogens $(3,8,30)$. The mechanism of action of medical plants and their extracts might be through their contribution in the stabilization of beneficial microflora and prevention of pathogens colonization in the gut of animals as well as improvement of digestive enzymes secretion and activity (23). Peppermint as a member of Labiate family is considered to be used widely in the world as a therapeutic herb (37). Peppermint's active compound like menthol, menthone, carvacrol, limonene, 1, 8cineol, cineol and $\alpha$-pinene play an important role as antimicrobials in inhibition the growth of Escherichia coli, Staphylococcus aureus, Salmonella enteritidis, and Candida albicans and as a coccidiostat targeting different life cycle stages of Eimeria species and subsequent improvement of poultry health and performance $(31,38)$. Thus the current study was aimed to determine the effect of powder peppermint (Mentha piperita) on the performance gut health, immune organs development, and serum biochemical parameters of coccidiosis challenged broilers.

\section{MATERIALS AND METHODS}

\section{Birds, diets, and husbandry}

A total of 320 d-old Ross 308 chicks were obtained from a private hatchery in Erbil province, Kurdistan region of Iraq. Birds were allocated to 32 floor pens in two separate rooms in the Animal production farm, College of Agricultural Engineering Sciences, University of Duhok. In a $2 \times 4$ factorial arrangement within Completely Randomized Design, birds were randomly weighed and assigned to 8 treatment groups of 4 replicates each, with 10 chicks per replicate. The four non challenged (NC) dietary treatments were: negative control (basal starter, grower and finisher diets with no additive), anticoccidial (basal diets supplemented with salinomycin at $60 \mathrm{mg} / \mathrm{kg}$ ), peppermint 1 (basal diets supplemented with $5 \mathrm{~g} / \mathrm{kg}(0.5 \%)$ peppermint powder), and peppermint 2 (basal diets supplemented with $10 \mathrm{~g} / \mathrm{kg}(1 \%)$ peppermint powder). The remaining four coccidiosis challenged (C) dietary treatments were [positive control (basal starter, grower and finisher diets with no additive and challenged with Eimeria), anticoccidial (basal diets supplemented with salinomycin at $60 \mathrm{mg} / \mathrm{kg}$ and challenged with Eimeria), peppermint 1 (basal diets supplemented with $5 \mathrm{~g} / \mathrm{kg}$ 
peppermint powder and challenged with Eimeria), and peppermint 2 (basal diets supplemented with $10 \mathrm{~g} / \mathrm{kg}$ peppermint powder and challenged with Eimeria)]. Nonchallenged birds were reared under sanitary conditions in the separate room to prevent the cross contamination with Eimeria. Birds were fed on starter diets from d 0 to 10 , grower diets from d 11 to 24 , and finisher diets from d 25 to 35 of experiment. Three basal diets were formulated according to the nutrient specifications of Ross 308 broilers (Table 1). The used peppermint powder was analyzed and its main active compounds show in Table 2. Birds were reared in floor pens (wire mesh partitioned at $100 \times 100 \mathrm{~cm}$ ) bedded with wood shavings. Temperature and lighting were set in accordance to management guidelines of the Ross 308 broiler strain. Birds were fed and watered ad libitum. On d 10, 24 and 35 of age, the remaining feed in the feeders and birds were weighed to measure the major determinants of performance including accumulative weight gain of birds, feed intake and feed conversion ratio of each pen. The experimental procedures were approved by Animal Ethics Committee at Department of Animal Production, College of Agricultural Engineering Sciences, University of Duhok under the approved number: AEC120120201.

Table1. Ingredients and composition of the basal starter, grower and finisher diets as percentage.

\begin{tabular}{|c|c|c|c|}
\hline Ingredients kg & Starter & Grower & Finisher \\
\hline Corn & 53.06 & 56.9 & 61.74 \\
\hline Soybean meal & 31.48 & 32.89 & 28.23 \\
\hline Fish meal & 4 & - & - \\
\hline Vegetable oil & 3 & 4.48 & 4.57 \\
\hline Limestone & 2 & 1.39 & 1.35 \\
\hline Dical Phos & 2.72 & 0.95 & 0.82 \\
\hline Salt & 0.11 & 0.19 & 0.08 \\
\hline D,L-methionine & 0.38 & 0.32 & 0.24 \\
\hline L-lysine HCl & 0.5 & 0.26 & 0.21 \\
\hline L-threonine & 0.25 & 0.13 & 0.09 \\
\hline Broiler premix & 2.5 & 2.5 & 2.5 \\
\hline \multicolumn{4}{|l|}{ Nutrient composition } \\
\hline ME (kcal/kg) & 3000 & 3150 & 3200 \\
\hline Crude protein & 23 & 21 & 19.16 \\
\hline Crude fiber & 2.25 & 2.38 & 2.33 \\
\hline Digestible Arginine & 1.29 & 1.14 & 0.99 \\
\hline Digestible Lysine & 1.29 & 1.14 & 0.99 \\
\hline Digestible Meth+Cyst & 0.87 & 0.84 & 0.73 \\
\hline Digestible Tryptophan & 0.226 & 0.24 & 0.21 \\
\hline Digestible Isoleucine & 0.87 & 0.81 & 0.73 \\
\hline Digestible Threonine & 0.82 & 0.73 & 0.63 \\
\hline Digestible Valine & 0.99 & 0.92 & $\mathbf{0 . 8 3}$ \\
\hline Calcium & 1.60 & 0.9 & 0.85 \\
\hline Available Phosphorus & 0.844 & 0.450 & 0.42 \\
\hline Sodium & 0.16 & 0.160 & 0.16 \\
\hline Chloride & 0.35 & 0.312 & 0.23 \\
\hline Linoleic & 2.18 & 2.64 & 2.73 \\
\hline
\end{tabular}

\section{Coccidia challenging}

The coccidia (Eimeria tenella) used in the present experiment was isolated in the laboratory of Animal Production Department, College of Agricultural Engineering Sciences, University of Duhok. Fresh bloody droppings were collected from infected birds in farms of the department. Samples of bloody droppings were transferred into $2 \mathrm{ml}$ Eppendorf tube then centrifuged at $6000 \mathrm{X} \mathrm{g}$ for 5 minutes and supernatant was discarded. The oocysts were allowed to sporulate in $2.5 \%(\mathrm{w} / \mathrm{v})$ potassium dichromate solution for three days at $27^{\circ} \mathrm{C}$. On day 8, challenged birds were inoculated with 5000 sporulated oocysts of Eimeria. Unchallenged birds were given $1 \mathrm{~mL}$ of $1 \%$ $(\mathrm{w} / \mathrm{v})$ sterile saline.

\section{Sample collection}

On day 24, two birds per replicate were randomly selected, weighed, and euthanized by cervical dislocation. Then, the birds were dissected to remove the small intestine. Weight of small intestine, gizzard and heart were recorded. The weights of immune organs 
(liver, spleen, bursa of Fabricius and) were also recorded and calculated as mass per unit of live body weight ( $\mathrm{g} / 100$ of live body weight). Approximately $1 \mathrm{~cm}$ of the jejunum and whole bursa of Fabricius from each of two bird per replicate were sampled. The intestinal specemens were gently flushed and cleaned with phosphate buffered saline (PBS, $\mathrm{pH}$ 7.4) and then fixed with bursa in $10 \%$ buffered formalin for subsequent morphometric analysis.

Table 2. The main active compounds of peppermint (Mentha piperita).

\begin{tabular}{|lcccc|}
\hline Initial concentration & \multicolumn{2}{c}{ DPPH Analysis (Inhibition \%) } & \multicolumn{2}{c|}{ CUPRAC Analysis (Inhibition \%) } \\
& Water Extract & Methanol Extract & Water Extract & Methanol Extract \\
\hline $1000 \mu \mathrm{g} / \mathrm{ml}$ & $\mathbf{8 1 . 0 3}$ & $\mathbf{8 5 . 1 9}$ & 3.74 & 3.63 \\
$\mathbf{5 0 0} \boldsymbol{\mu \mathrm { g } / \mathrm { ml }}$ & $\mathbf{6 4 . 7 8}$ & $\mathbf{7 4 . 7 8}$ & 2.32 & $\mathbf{2 . 3 1}$ \\
$\mathbf{2 5 0} \boldsymbol{\mu \mathrm { g } / \mathrm { ml }}$ & $\mathbf{4 7 . 7 5}$ & $\mathbf{5 6 . 7 5}$ & $\mathbf{1 . 2 6}$ & $\mathbf{1 . 2 5}$ \\
$\mathbf{1 2 5} \boldsymbol{\mu \mathrm { g } / \mathrm { ml }}$ & $\mathbf{3 4 . 5 7}$ & $\mathbf{4 2 . 5 7}$ & $\mathbf{0 . 8 1}$ & $\mathbf{0 . 8 0}$ \\
$\mathbf{6 2 . 5} \boldsymbol{\mu \mathrm { g } / \mathrm { ml }}$ & $\mathbf{2 7 . 8 5}$ & $\mathbf{3 1 . 8 5}$ & $\mathbf{0 . 5 4}$ & \\
\hline Content \pm SD & Water Extract & Methanol Extract & & \\
Inhibition\% \pm SD & & & & \\
\hline Total Phenolic & $\mathbf{1 0 2 . 6 7 1} \pm \mathbf{0 . 9 8}$ & $\mathbf{9 0 . 8 7 9} \pm \mathbf{1 . 0 2}$ & & \\
Total flavonoid & $\mathbf{2 1 . 4 6 4} \pm \mathbf{0 . 3 6}$ & $\mathbf{2 6 . 0 2 3} \pm \mathbf{0 . 6 1}$ & & \\
AChE & $\mathbf{9 0 . 2 8} \pm \mathbf{0 . 3 6}$ & $\mathbf{9 4 . 1 6} \pm \mathbf{0 . 2 5}$ & & \\
BChE & $\mathbf{8 6 . 0 6} \pm \mathbf{1 . 1 2}$ & $\mathbf{8 8 . 5 5} \pm \mathbf{0 . 1 9}$ & & \\
\hline
\end{tabular}

DPPH (diphenyl-2-picrylhydrazil Inhibition), CUPRAC (CUPric Reducing Antioxidant Capacity), (AChE) Acetylcolinesterase, (BChE) Butyrylcholinesterase. "Own analysis.

Measurements and processing

Histology: Fixed samples of intestine and bursa of Fabricius were dried, cleared and fixed in paraffin wax for later histological analysis. The sequent longitudinal sections (7 $\mu \mathrm{m}) \quad$ were placed individually onto Superfrost ${ }^{\circledR}$ slides (Thermo Scientific, Rockville, MD, USA) and stained with hematoxylin and eosin. Villus height, villus apical width at the tip of the villus, villus basal width at the crypt-villus junction, crypt depth, muscularis depth (thickness), length of lymphoid follicles, width of lymphoid follicles, and follicular area were measured on 10 villi and 10 lymphoid follicles of bursa per sampled broiler using the Dino-eye program by analyzing the images captured with a color video camera (Dino-eye 20). The villi height: crypt depth ratio (VH:CD) per broiler was calculated by dividing the average of the 10 measured villi heights by the average of the 10 measured crypt depth.of the same broiler. The apparent villus surface area was found out using the formula: $\{[($ villus tip + villus base)/2] $\times$ villus height $\}$ (21). The area of bursa lymphoid follicles was measured by drawing a around the selected follicles.

\section{Serum biochemical}

On day 24 of age, peripheral blood samples were taken from the jugular vein of two birds per pen and serum was separated for estimating of total protein, albumin, cholesterol, alanine transaminase (ALT) and aspartate aminotransferase (AST) using an automatic COBAS INTEGRA400 plus analyzer (Cedex Bio HT Analyzer).

\section{Statistical Analysis}

The SAS statistical package (PROC GLM) was used to test the homogeneity of variances and normality of data as well as to determine significance and interactions of main effects (SAS, 2013). When interactions were observed $(P<0.05)$, Duncan's multiple range test was used to detect the differences between individual treatment means.

\section{RESULTS AND DISCUSSION}

\section{Broilers' performance}

Performance results of broilers are show in Tables 3-5. Table 3 shows that from d 0 to $d$ 10, challenged broilers had lower weight gain (WG) $(P<0.05)$ and strongly tended to have poorer feed conversion ratio (FCR) $(P=$ 0.0520) compared to non-challenged birds. Feed intake (FI) of broilers given 1\% peppermint was lower than those given salinomycin $(P<0.05)$. Challenge $\mathrm{x}$ additive interaction was existing for FI $(P<0.05)$ but was not for WG and FCR $(P>0.05)$. Challenged broilers in $1 \%$ peppermint treatment consumed less feed $(P<0.05)$ compared to those in Negative Control and non-challenged salinomycin groups of broilers. From d 0 to d 24 there were no significant differences in growth performance of challenged and non-challenged broilers despite of Eimeria's strong tendency to 
negatively affect FCR $(\mathrm{P}=0.0566)$ (Table 4$)$. Broilers given both concentrations of peppermint and salinomycin had higher WG $(\mathrm{P}<0.0001)$ and better FCR $(\mathrm{P}<0.05)$ compared to controls. Broilers fed $0.5 \%$ peppermint had higher WG than those fed $1 \%$ peppermint $(\mathrm{P}<0.0001)$. Challenge $\mathrm{x}$ additive interactions were present for $\mathrm{WG}$ and FCR $(\mathrm{P}$ $<0.0001)$ as well as for FI $(\mathrm{P}<0.05)$. Positive

Table 3. Effect of different treatments on broilers' performance from $\mathrm{d} 0$ to $\mathrm{d} 10 \mathrm{of}$ age.

\begin{tabular}{|c|c|c|c|}
\hline Treatments $^{*}$ & Weight gain g/bird & Feed Intake g/bird & FCR \\
\hline Negative control & 247.75 & $295.500^{\mathrm{ab}}$ & 1.199 \\
\hline NC Salinomycin & 253.75 & $302.500^{\mathrm{a}}$ & 1.194 \\
\hline NC $0.5 \%$ peppermint & 255.00 & $291.750^{\mathrm{bc}}$ & 1.147 \\
\hline NC $1 \%$ peppermint & 249.50 & $295.000^{\mathrm{ab}}$ & 1.184 \\
\hline Positive control & 234.25 & $293.000^{\mathrm{bc}}$ & 1.254 \\
\hline C Salinomycin & 249.25 & $296.750^{\mathrm{ab}}$ & 1.193 \\
\hline C $0.5 \%$ peppermint & 235.25 & $296.250^{\mathrm{ab}}$ & 1.263 \\
\hline C $1 \%$ peppermint & 233.25 & $286.000^{c}$ & 1.229 \\
\hline Pooled SEM & 2.786 & 1.118 & 0.013 \\
\hline \multicolumn{4}{|l|}{ Main effects } \\
\hline \multicolumn{4}{|l|}{ Challenge } \\
\hline None & $252.75^{\mathrm{a}}$ & 296.42 & 1.175 \\
\hline Eimeria & $239.25^{\mathrm{b}}$ & 293.00 & 1.228 \\
\hline \multicolumn{4}{|l|}{ Additive } \\
\hline Control & 241.00 & $294.25^{\mathrm{ab}}$ & 1.226 \\
\hline Salinomycin & 251.50 & $299.63^{\mathrm{a}}$ & 1.193 \\
\hline $0.5 \%$ Peppermint & 245.13 & $294.00^{\text {ab }}$ & 1.205 \\
\hline $1 \%$ Peppermint & 241.38 & $290.50^{b}$ & 1.207 \\
\hline \multicolumn{4}{|l|}{$\mathbf{P}>\mathbf{F}$} \\
\hline Challenge & 0.0255 & 0.2494 & 0.0520 \\
\hline Additive & 0.5344 & 0.0275 & 0.8491 \\
\hline Challenge $x$ additive & 0.2343 & 0.0107 & 0.3445 \\
\hline
\end{tabular}

$\mathrm{a}, \mathrm{b}-$ Means within the same column with different superscripts differ significantly at $(\mathrm{P}<0.05)$.

*Negative control $=$ Basal diet $($ No additive + No challenge $)$. Positive control $=$ Basal diet $($ No additive + challenged with Eimeria $)$. NC = Non-challenged with Eimeria $. \mathrm{C}=$ Challenged with Eimeria .

Furthermore, broilers fed $0.5 \%$ peppermint had markedly higher WG compared to those of the all other challenged and non-challenged treatments $(\mathrm{P}<0.0001)$. Negative control broilers and non-challenged ones fed $1 \%$ peppermint consumed less feed compared to those of the all other groups except the challenged broilers fed salinomycin $(P<0.05)$. Positive control broilers had poorer FCR compared to those of the all other challenged and non-challenged treatments $(\mathrm{P}<0.0001)$. Also, FCR of non-challenged broilers fed $0.5 \%$ peppermint was better than challenged broilers fed $1 \%$ peppermint and negative (challenged) control broilers had lower WG compared to those of the all other treatments and negative (non-challenged) controls ( $\mathrm{P}<$ $0.0001)$. On the other hand, broilers of the all challenged and non-challenged treatments except the challenged ones fed $1 \%$ peppermint had higher WG compared to negative controls $(\mathrm{P}<0.0001)$. 
controls than in non-challenged broilers compared to negative controls. Positive control broilers had lower WG and poorer FCR compared to negative control and the all other challenged and non-challenged broilers $(P<$ 0.0001). Also, non-challenged broilers fed salinomycin and both concentrations of peppermint had greater WG compared to challenged broilers given $0.5 \%$ and $1 \%$ of peppermint $(P<0.0001)$. Non-challenged broilers in both peppermint groups consumed more feed than those in negative control and challenged ones in both peppermint and salinomycin groups $(P<0.05)$.

Table 4. Effect of different treatments on broilers' performance from d 0 to $d 24$ of age.

\begin{tabular}{|c|c|c|c|}
\hline Treatments $^{*}$ & Weight gain g/bird & Feed Intake g/bird & FCR \\
\hline Negative control & $982.25^{\mathrm{c}}$ & $1369.00^{b}$ & $1.394^{b}$ \\
\hline NC Salinomycin & $1057.00^{b}$ & $1432.5^{a}$ & $1.356^{\mathrm{bc}}$ \\
\hline NC $0.5 \%$ peppermint & $1134.50^{\mathrm{a}}$ & $1463.75^{a}$ & $1.291^{\mathrm{c}}$ \\
\hline NC $1 \%$ peppermint & $1052.75^{b}$ & $1379.5^{b}$ & $1.313^{b c}$ \\
\hline Positive control & $881.75^{d}$ & $1466.75^{a}$ & $1.670^{\mathrm{a}}$ \\
\hline C Salinomycin & $1053.75^{b}$ & $1417.50^{\mathrm{ab}}$ & $1.345^{b c}$ \\
\hline C $0.5 \%$ peppermint & $1068.25^{b}$ & $1437.25^{a}$ & $1.346^{\mathrm{bc}}$ \\
\hline C $1 \%$ peppermint & $1039.00^{\text {bc }}$ & $1432.50^{\mathrm{a}}$ & $1.379^{b}$ \\
\hline Pooled SEM & 13.878 & 7.852 & 0.022 \\
\hline Main effects & & & \\
\hline \multicolumn{4}{|l|}{ Challenge } \\
\hline None & 1081.42 & 1425.25 & 1.320 \\
\hline Eimeria & 1053.67 & 1429.08 & 1.357 \\
\hline \multicolumn{4}{|l|}{ Additive } \\
\hline Control & $932.00^{c}$ & 1417.88 & $1.532^{\mathrm{a}}$ \\
\hline Salinomycin & $1055.38^{a b}$ & 1425.00 & $1.351^{b}$ \\
\hline $0.5 \%$ Peppermint & $1101.38^{a}$ & 1450.50 & $1.318^{b}$ \\
\hline $\begin{array}{l}1 \% \text { Peppermint } \\
\text { P }>\text { F }\end{array}$ & $1045.88^{b}$ & 1406.00 & $1.346^{b}$ \\
\hline Challenge & 0.1073 & 0.8055 & 0.0566 \\
\hline Additive & $<.0001$ & 0.2347 & 0.0002 \\
\hline Challenge $x$ additive & $<.0001$ & 0.0022 & $<.0001$ \\
\hline
\end{tabular}

a, b, c - Means within the same column with different superscripts differ significantly at $(\mathbf{P}<0.05)$. "See Table 3 for details of treatments

Table 5. Effect of different treatments on broilers' performance from d 0 to d 35 of age.

\begin{tabular}{|c|c|c|c|}
\hline Treatments $^{*}$ & Weight gain g/bird & Feed Intake g/bird & FCR \\
\hline Negative control & $1894.75^{\mathrm{ab}}$ & $2794.25^{b}$ & $1.475^{b}$ \\
\hline NC Salinomycin & $1957.00^{\mathrm{a}}$ & $2829.25^{\mathrm{ab}}$ & $1.446^{b}$ \\
\hline NC $0.5 \%$ peppermint & $1974.25^{a}$ & $2915.25^{a}$ & $1.477^{b}$ \\
\hline NC $1 \%$ peppermint & $1977.75^{a}$ & $2924.75^{a}$ & $1.478^{b}$ \\
\hline Positive control & $1698.00^{c}$ & $2859.00^{\mathrm{ab}}$ & $1.686^{\mathrm{a}}$ \\
\hline C Salinomycin & $1902.75^{\mathrm{ab}}$ & $2783.75^{b}$ & $1.463^{b}$ \\
\hline C $0.5 \%$ peppermint & $1860.50^{b}$ & $2786.75^{b}$ & $1.498^{b}$ \\
\hline C $1 \%$ peppermint & $1844.50^{b}$ & $2767.00^{b}$ & $1.500^{b}$ \\
\hline Pooled SEM & 17.408 & 15.650 & 0.014 \\
\hline \multicolumn{4}{|l|}{ Main effects } \\
\hline Challenge & & & \\
\hline None & $1969.67^{a}$ & $2889.75^{a}$ & $1.467^{b}$ \\
\hline $\begin{array}{l}\text { Eimeria } \\
\text { Additive }\end{array}$ & $1869.25^{b}$ & $2779.17^{b}$ & $1.488^{\mathrm{a}}$ \\
\hline Control & $1796.38^{b}$ & 2826.63 & $1.58025^{a}$ \\
\hline Salinomycin & $1929.88^{a}$ & 2806.50 & $1.45450^{b}$ \\
\hline $0.5 \%$ Peppermint & $1917.38^{a}$ & 2851.00 & $1.48725^{b}$ \\
\hline $\begin{array}{l}1 \% \text { Peppermint } \\
\text { P }>\text { F }\end{array}$ & $1911.13^{a}$ & 2845.88 & $1.48925^{b}$ \\
\hline Challenge & $<.0001$ & 0.0007 & 0.0386 \\
\hline Additive & 0.0151 & 0.7579 & 0.0051 \\
\hline Challenge $x$ additive & $<.0001$ & $\mathbf{0 . 0 3 7 0}$ & $<.0001$ \\
\hline
\end{tabular}

a, b,c - Means within the same column with different superscripts differ significantly at $(P<0.05)$. "See Table 3 for details of treatments 
Meat type chickens' performance is highly related to their gut's growth and health. The gut's health has a significant role in attaining high productivity. It influences feed digestion, nutrients metabolism and their absorption and utilization particularly energy and protein as well as it affects the resistance of broilers to diseases (29). In the last few decades medicinal plants such as Peppermint, Oregano, Rosemary etc. have been interestingly used as feed additives for improvement of broilers' performance under normal conditions. However to my knowledge there are no published data on the effect of whole peppermint plant and little ones on the effect of essential oils derived from peppermint in controlling of coccidiosis in broilers. In the current study, the coccidiosis infection was successfully induced as demonstrated by declined WG and FI as well as poor FCR in challenged broilers at the all three phases of the rearing. The positive effect of peppermint on the performance of broilers was obviously appeared from d 0 to 24 and d 0 to 35 of age. Peppermint not only had the same ability of salinomycin in protecting the performance of challenged broilers, but also greatly improved the WG and FCR of challenged and nonchallenged broilers. This was similar case of Barbour et. al., (8) who reported that giving coccidian-challenged broilers a commercial blend containing eucalyptus and peppermint essential oils (EOs) in drinking water had increased body weight (BW), improved FCR, and decreased mortality percentage. Also Nameghi et. al., (32) demonstrated that adding a blend of essential oils (EOB) extracted from thyme, peppermint and eucalyptus to drinking water had improved broilers WG and FCR. Similarly, Abdullah and Al-Barwary (3) found that addition of Artemisia as a medicinal plant to feed and drinking water of coccidiosis challenged broilers improved their WG and FCR. Furthermore, Hasan and M'Sadeq (16) demonstrated that WG and FCR of E. coli challenged broilers were enhanced when given diets and drinking water supplemented with peppermint powder. In contrast, Asadi et al., (7) and Ocak et al., (33) found that in-feed giving of peppermint to broilers did not significantly improved their daily WG at starter and finisher periods of rearing. The beneficial effects of peppermint powder or its derived EOs on the performance of the broilers could be due to the improvement of feed digestibility and nutrients' absorption especially lipids. This might be resulted from the peppermint and other herbal plants' content of active compounds like carvacrol, menthol, thymol, $\rho$-cymene, 1,8-cineol, menthone, $\gamma$-terpinene and $\alpha$-pinene which stimulate the secretion of salivaand endogenous enzymes like amylase and enhance the synthesis of bile acid in liver and the excretion of bile acids which will improve the digestion and absorption of lipids $(14,31$, 40). The better growth performance of broilers in the current experiment might be also due to the significant improvement of their gut health through increasing of villus height and $\mathrm{VH}: \mathrm{CD}$ ratio and reducing of crypt depth.

\section{Visceral organs relative weight}

Relative weight of broilers' visceral organs to their live body weight are illustrated in Table 6. It is noted that Eimeria challenged broilers had significantly lower relative weight of liver in comparison with non-challenged ones. $0.5 \%$ peppermint supplemented broilers had relatively heavier intestines weight compared to the all other treatments $(P<0.05)$. There was a tendency for the relative weight of bursa of Fabricius of broilers of both additives particularly $0.5 \%$ peppermint to be higher than those of the controls $(P=0.099)$. Also a strong tendency of challenge $\mathrm{x}$ additive interaction was observed for relative weight of intestines $(\mathrm{P}=0.059)$. In the present study the relative weight of edible visceral organs was not influenced by experimental factors except that the relative weight of liver of challenged broilers was less than those of non-challenged ones. This was in agreement with what demonstrated by Huff and Ruff (20) that Eimeria tenella significantly decreased the relative weight of broilers' liver compared to un-inoculated broilers. In contrast, Brito et al., (10) found that Eimeria maxima significantly increased the relative weight of the liver. 
Table 6. Effect of different treatments on relative internal organs' weights $(\mathrm{g} / 100 \mathrm{~g} \mathrm{BW})$ of broilers at $d 24$ of age.

\begin{tabular}{|c|c|c|c|c|c|c|}
\hline Treatments* $^{*}$ & Liver & Heart & Spleen & Gizzard & $\begin{array}{c}\text { Small } \\
\text { Intestine }\end{array}$ & $\begin{array}{c}\text { Bursa of } \\
\text { Fabricius } \\
\end{array}$ \\
\hline Negative control & 3.11 & 0.78 & 0.10 & 3.73 & 7.08 & 0.147 \\
\hline NC Salinomycin & 3.19 & 0.71 & 0.09 & 3.82 & 6.64 & 0.153 \\
\hline NC $0.5 \%$ peppermint & 3.73 & 0.99 & 0.16 & 4.36 & 10.10 & 0.238 \\
\hline NC $1 \%$ peppermint & 3.20 & 0.74 & 0.09 & 4.57 & 7.20 & 0.167 \\
\hline Positive control & 2.82 & 0.61 & 0.10 & 3.96 & 6.54 & 0.210 \\
\hline C Salinomycin & 2.77 & 0.57 & 0.10 & 3.73 & 6.06 & 0.206 \\
\hline C $0.5 \%$ peppermint & 2.81 & 0.62 & 0.11 & 3.87 & 7.68 & 0.236 \\
\hline C $1 \%$ peppermint & 2.76 & 0.61 & 0.11 & 4.13 & 6.38 & 0.192 \\
\hline Pooled SEM & 0.100 & 0.045 & 0.007 & 0.101 & 0.337 & 0.010 \\
\hline \multicolumn{7}{|l|}{ Main effects } \\
\hline \multicolumn{7}{|l|}{ Challenge } \\
\hline None & $3.374^{\mathrm{a}}$ & 0.814 & 0.110 & 4.250 & 7.980 & 0.186 \\
\hline Eimeria & $2.777^{b}$ & 0.603 & 0.105 & 3.910 & 6.708 & 0.211 \\
\hline \multicolumn{7}{|l|}{ Additive } \\
\hline Control & 2.964 & 0.693 & 0.104 & 3.842 & $6.811^{b}$ & 0.178 \\
\hline Salinomycin & 2.981 & 0.642 & 0.094 & 3.776 & $6.350^{b}$ & 0.179 \\
\hline $0.5 \%$ Peppermint & 3.268 & 0.808 & 0.133 & 4.117 & $8.889^{\mathrm{a}}$ & 0.237 \\
\hline 1\% Peppermint & 2.977 & 0.676 & 0.096 & 4.347 & $6.793^{b}$ & 0.180 \\
\hline \multicolumn{7}{|l|}{$\mathbf{P}>\mathbf{F}$} \\
\hline Challenge & 0.012 & 0.072 & 0.780 & 0.203 & 0.158 & 0.331 \\
\hline Additive & 0.678 & 0.621 & 0.120 & 0.167 & 0.027 & 0.098 \\
\hline Challenge $x$ additive & 0.190 & 0.351 & 0.204 & 0.338 & 0.059 & 0.139 \\
\hline
\end{tabular}

a, b - Means within the same column with different superscripts differ significantly at $(P<0.05)$. "See Table 3 for details of treatments.

In the current study the absence of peppermint's effectiveness on the relative weight of edible internal organs of broilers is in consistent with findings of Abdel-Wareth et al., (2) who reported that supplementation of menthol and peppermint leaves to broiler's diet did not affect the relative weight of pancreas, gizzard, heart, liver and spleen. However, Asadi et al., (7) stated that different levels of peppermint significantly increased the relative weight of broilers' gizzard, liver and heart.

\section{Gut morphology}

Eimeria challenged broilers had significantly shorter jejunal villi, deeper crypt, lower ratio of villus height to crypt depth (VH:CD) and wider villus base $(P<0.05, P<0.0001)$ compared to non-challenged broilers (Table 7). Salinomycin and both peppermint concentrations fed broilers had longer jejunal villi $(P<0.0001)$ compared to those fed no additives. Also, salinomycin fed broilers had longer villus in comparison with those fed both peppermint concentrations $(P<0.0001)$. Crypt depth was reduced in broilers given $0.5 \%$ and $1 \%$ peppermint $(P<0.05)$ compared to those fed no additives diet and salinomycin. Broilers fed basal diet without additives had wider villus tip compared to those fed salinomycin and both peppermint concentrations $(P<0.05)$. Both concentrations of peppermint significantly decreased width of broilers' jejunal villus base compared to the controls and reduced apparent surface area of villus in comparison with those fed salinomycin added and non-supplemented control diets $(P<0.05)$. The thickness of jejunum muscle of broilers fed $0.5 \%$ peppermint was lower $(P<0.0001)$ than those of control and salinomycin groups. In addition salinomycin fed broilers had thicker jejunal muscles $(P<0.0001)$ compared to those fed both peppermint concentrations. Challenge $\mathrm{x}$ additive interactions were markedly present 
for villus height, crypt depth, VH:CD ratio, thickness of jejunum muscle at $(P<0.0001)$ and for width of villus tip, width of villus base, apparent villus surface area at $(P<0.05)$. The villus height and jejunum muscle thickness of non-challenged salinomycin fed broilers were higher than those of the all other nonchallenged treatments $(P<0.0001)$. Also, nonchallenged control broilers had significantly wider villus tip and base compared to those of the all other non-challenged broiler groups. Furthermore, broilers of non-challenged control had larger apparent villus surface area compared to those of non-challenged $0.5 \%$ and $1 \%$ peppermint ones $(P<0.05)$. However, there were not significant differences between treatments in terms of crypt depth and $\mathrm{VH}: \mathrm{CD}$ $(P>0.05)$. Under the coccidiosis challenge condition, peppermint had positive impact on the morphology of the jejunum. Broilers received salinomycin and both peppermint concentrations showed an increase in villus height and VH:CD ratio, and a decrease in crypt depth and thickness of jejunum muscle with respect to those fed control diet $(P<$ 0.0001). In addition, salinomycin fed broilers had taller villus and thicker jejunum muscle compared to those fed only $0.5 \%$ peppermint $(P<0.0001)$, and had deeper crypt $(P<$ $0.0001)$ and wider villus base $(P<0.05)$ compared to those fed both peppermint concentrations. Moreover, broilers given salinomycin had larger apparent villus surface area in comparison with control, $0.5 \%$ and $1 \%$ peppermint fed ones $(P<0.05)$. However, there were no significant differences in width of the villus tip between control broilers and those fed salinomycin and both peppermint concentrations. General health status and subsequent growth performance are directly correlated to their gastrointestinal health. Integrity and health of bird's alimentary tract is related to their gut morphology.

Table 7. Effect of different treatments on jejunum muscle thickness, villus height, crypt depth and apparent villus surface of broilers at $\mathrm{d} 24$ of age.

\begin{tabular}{|c|c|c|c|c|c|c|c|}
\hline Treatments $^{*}$ & $\begin{array}{c}\text { Villus } \\
\text { height } \\
\mu m \text { VH }\end{array}$ & $\begin{array}{c}\text { Crypt } \\
\text { depth } \\
\mu m \text { CD }\end{array}$ & $\begin{array}{c}\mathrm{VH} / \mathrm{CD} \\
\text { ratio }\end{array}$ & $\begin{array}{c}\text { villus tip } \\
\text { width } \\
\mu m\end{array}$ & $\begin{array}{c}\text { villus } \\
\text { base } \\
\text { width } \\
\mu m\end{array}$ & $\begin{array}{c}\text { apparent } \\
\text { villus surface } \\
\text { area } \mu m^{2}\end{array}$ & $\begin{array}{c}\text { Jejunum } \\
\text { muscle } \\
\text { thickness } \mu m\end{array}$ \\
\hline Negative control & $945^{\mathrm{bc}}$ & $183^{\mathrm{c}}$ & $5.55^{\mathrm{a}}$ & $241^{a}$ & $247^{\mathrm{a}}$ & $230151^{a}$ & $204^{c}$ \\
\hline NC Salinomycin & $1109^{\mathrm{a}}$ & $211^{\mathrm{c}}$ & $5.43^{\mathrm{a}}$ & $163^{b}$ & $169^{b}$ & $185019^{a b}$ & $265^{b}$ \\
\hline NC $0.5 \%$ peppermint & $997^{b}$ & $172^{\mathrm{c}}$ & $5.89^{\mathrm{a}}$ & $137^{b}$ & $162^{b}$ & $148643^{b}$ & $212^{\mathrm{c}}$ \\
\hline NC $1 \%$ peppermint & $939^{\mathrm{bc}}$ & $171^{\mathrm{c}}$ & $5.65^{\mathrm{a}}$ & $163^{b}$ & $168^{b}$ & $156172^{b}$ & $210^{c}$ \\
\hline Positive control & $762^{d}$ & $402^{\mathrm{a}}$ & $1.91^{\mathrm{c}}$ & $179^{b}$ & $208^{a b}$ & $146084^{b}$ & $330^{\mathrm{a}}$ \\
\hline C Salinomycin & $1008^{b}$ & $311^{\mathrm{b}}$ & $3.82^{\mathrm{b}}$ & $182^{b}$ & $242^{\mathrm{a}}$ & $211454^{a}$ & $262^{b}$ \\
\hline C $0.5 \%$ peppermint & $914^{c}$ & $231^{\mathrm{c}}$ & $4.09^{b}$ & $139^{b}$ & $174^{\mathrm{b}}$ & $142659^{b}$ & $208^{c}$ \\
\hline C $1 \%$ peppermint & $977^{\mathrm{bc}}$ & $229^{c}$ & $4.39^{b}$ & $156^{b}$ & $164^{b}$ & $157465^{b}$ & $242^{b c}$ \\
\hline Pooled SEM & 9.59 & 7.42 & 0.13 & 5.74 & 6.89 & 5630.99 & 4.87 \\
\hline \multicolumn{8}{|l|}{$\begin{array}{l}\text { Main effects } \\
\text { Challenge }\end{array}$} \\
\hline None & $1015^{\mathrm{a}}$ & $186^{b}$ & $5.61^{\mathrm{a}}$ & 158 & $167^{\mathrm{b}}$ & 165793 & 231 \\
\hline $\begin{array}{c}\text { Eimeria } \\
\text { Additive }\end{array}$ & $975^{b}$ & $270^{\mathrm{a}}$ & $4.02^{b}$ & 165 & $206^{\mathrm{a}}$ & 180422 & 243 \\
\hline Control & $889^{c}$ & $251^{\mathrm{a}}$ & 4.43 & $222^{\mathrm{a}}$ & $235^{\mathrm{a}}$ & $204284^{a}$ & $243^{a b}$ \\
\hline Salinomycin & $1064^{\mathrm{a}}$ & $255^{\mathrm{a}}$ & 4.72 & $172^{b}$ & $201^{\text {ab }}$ & $196650^{\mathrm{a}}$ & $264^{\mathrm{a}}$ \\
\hline $0.5 \%$ Peppermint & $959^{b}$ & $199^{b}$ & 5.06 & $138^{b}$ & $168^{b}$ & $145881^{b}$ & $210^{c}$ \\
\hline $\begin{array}{l}\text { 1\% Peppermint } \\
\text { P }>\text { F }\end{array}$ & $948^{b}$ & $185^{b}$ & 5.34 & $162^{b}$ & $167^{b}$ & $156487^{b}$ & $218^{b c}$ \\
\hline Challenge & 0.0469 & $<.0001$ & $<.0001$ & 0.5159 & 0.0060 & 0.2027 & 0.2724 \\
\hline Additive & $<.0001$ & 0.0002 & 0.1187 & 0.0015 & 0.0120 & 0.0004 & $<.0001$ \\
\hline Challenge $x$ additive & $<.0001$ & $<.0001$ & $<.0001$ & 0.0075 & 0.0013 & 0.0006 & $<.0001$ \\
\hline
\end{tabular}

a, b, $c$ - Means within the same column with different superscripts differ significantly at $(\mathrm{P}<0.05)$. "See Table 3 for details of treatments 
The VH:CD ratio is a significant index of retrieval and health. High ratio indicating a long, mature, active and functional villus companying with a thin crypt and continual renewal of cells (30). Findings of the current study revealed that coccidian has dramatically changed the gastrointestinal morphology of broilers. At d 24 of age and post Eimeria challenge, positive control (challenged control) broilers had significantly shorter villus length, lower $\mathrm{VH}: \mathrm{CD}$ ratio and deeper crypt compared to negative control (nonchallenged control) and challenged broilers fed salinomycin and peppermint supplemented diets. This was similar to outcomes of a study by M'Sadeq et al., (30) when Eimeria has severely impaired the morphology of broilers' jejunum. Authors indicated that existence of pathogens in the gut is considered to enterocyte cells damage resulting in deeper crypts. The deeper crypts would require higher energy utilization for maintaining of intestine instead of its using for improvement of growth performance. This means that in the current study peppermint had the same ability of salinomycin in improvement of the health and morphology of coccidian challenged broilers. In the recent times a great attention has been paid to aromatic plants and their extracts. This is due to their capability of gut flora manipulation (17), antimicrobial characteristics by changing the properties of cell membranes and causing ion leakage and subsequent reduction of microbes virulence $(35,42)$, boosting of the immune response (15) as well as antiparasitic and coccidiostat properties through their flavonoid and phenolic compounds by retarding the growth and reproduction of coccidian parasite and decreasing of its oocyst count $(5,43)$. In the present study broilers' gut health protection and its morphological improvement resulted from peppermint supplementation are similar to findings of Mehri et al., (26) who demonstrated that in-feed peppermint increased the VH:CD ratio in ileum of quails. Similarly Hasan and M'Sadeq (16) found that peppermint in feed or drinking water of $E$. coli challenged broilers increased the $\mathrm{VH}: \mathrm{CD}$ ratio while it had no effect on villus height. Also Abdullah and Al-Barwary (3) demonstrated that Artemisia splendens as a herb increased villus height and $\mathrm{VH}: \mathrm{CD}$ ratio and decreased crypt depth of Eimeria challenged broilers' jejunum. However, Guo et al., (15) reported that the medicinal plants had no significant impact on the morphometric measurements of intestine when compared with control and antibiotic.

\section{Cloacal bursa morphology}

The morphometric measurements of bursa of Fabricius at d 24 of age are given in Table 8 . The bursal lymphoid follicles of Eimeria challenged broilers had longer, wider and larger area compared to those of nonchallenged broilers $(P<0.05)$. There were no significant differences between additives fed broilers and controls in bursa morphological parameters $(P>0.05)$. Challenge $\mathrm{x}$ additive interactions were observed for length and area of bursa lymphoid follicles $(P<0.05)$. The challenged broilers fed control diet with no additives had significantly longer bursal lymphoid follicles compared to challenged ones fed $1 \%$ peppermint and larger area of bursal lymphoid follicles compared to challenged broilers fed $0.5 \%$ and $1 \%$ peppermint. No significant differences were observed between non-challenged treatments of broilers in terms of bursa morphometric measurements. The bursa of Fabricius as one of the primary lymphoid organs is the site of the B lymphocytes differentiation and development involves in the acquired immune function by secretion of antibodies that bind to antigens (34). The integrity of bursa and other lymphoid tissues is critical for proper immune modification (4). In the present study the numerical increase in the relative weight of bursa of Fabricius and the significant increase in the length, width, and area of its lymphoid follicles in Eimeria challenged broilers might be due to the enlargement of its epithelium resulted from developing of Eimeria tenella in the bursa of Fabricius $(6,18)$. 
Table 8. Effect of different treatments on morphometric cloacal bursa measurements of broilers at d24 of age.

\begin{tabular}{|c|c|c|c|}
\hline Treatments* & $\begin{array}{l}\text { Bursa Lymphoid } \\
\text { follicles length } \mu m\end{array}$ & $\begin{array}{l}\text { Bursa Lymphoid } \\
\text { follicles width } \mu m\end{array}$ & $\begin{array}{c}\text { Bursa Lymphoid follicles } \\
\text { area } \\
\mu m^{2}\end{array}$ \\
\hline Negative control & 5018 $^{\mathrm{b}}$ & 2985 & $12909^{b}$ \\
\hline NC Salinomycin & $4559^{b}$ & 3020 & $11563^{b}$ \\
\hline NC $0.5 \%$ peppermint & $4649^{b}$ & 2847 & $10845^{b}$ \\
\hline NC $1 \%$ peppermint & $4774^{b}$ & 2967 & $12265^{b}$ \\
\hline Positive control & $6576^{a}$ & 3995 & $21532^{\mathrm{a}}$ \\
\hline C Salinomycin & $5610^{\mathrm{ab}}$ & 3604 & $16538^{a b}$ \\
\hline C $0.5 \%$ peppermint & $5604^{\mathrm{ab}}$ & 3323 & $14592^{b}$ \\
\hline C $1 \%$ peppermint & $5_{323}{ }^{b}$ & 3407 & $14024^{b}$ \\
\hline Pooled SEM & 156.6 & 118.2 & 896.7 \\
\hline \multicolumn{4}{|l|}{ Main effects } \\
\hline \multicolumn{4}{|l|}{ Challenge } \\
\hline None & $4661^{b}$ & $2945^{b}$ & $11558^{b}$ \\
\hline Eimeria & $5512^{\mathrm{a}}$ & $3445^{\mathrm{a}}$ & $15051^{\mathrm{a}}$ \\
\hline \multicolumn{4}{|l|}{ Additive } \\
\hline Control & 5797 & 3490 & 17221 \\
\hline Salinomycin & 5085 & 3312 & 14050 \\
\hline 0.5\% Peppermint & 5127 & 3085 & 12718 \\
\hline 1\% Peppermint & 5049 & 3187 & 13145 \\
\hline \multicolumn{4}{|l|}{$\mathbf{P}>\mathbf{F}$} \\
\hline Challenge & 0.0050 & 0.0035 & 0.0110 \\
\hline Additive & 0.2818 & 0.6728 & 0.2847 \\
\hline Challenge $x$ additive & 0.0081 & 0.2024 & 0.0484 \\
\hline
\end{tabular}

a, b - Means within the same column with different superscripts differ significantly at $(\mathrm{P}<0.05)$. "See Table 3 for details of treatments.

Anderson et al., (6) and Helal et al., (18) have reported the existence of Eimeria tenella's life cycle in the bursa of Fabricius of broilers. Bursal fold and lymphoid follicles' epithelial hyperplasia might be an indicator of the presence of an early cellular immune function against invading Eimeria tenella (22). This was investigated by Ilić et al. (22) through detecting of CD3-T lymphocyte population in bursa of Fabricius of Eimeria tenella infected broilers. In the present study, the significantly less enlarged bursa of challenged peppermint fed broilers compared to challenged controls could be due to their better intestine's health and integrity resulted from Oocysticidal activity of peppermint's essential oils by decreasing of coccidian Oocyst count (13).

\section{Serum biochemical profile}

The effect of Eimeria and different additives on the broilers' serum biochemical traits at d 24 of age are presented in Table 9. The results revealed that, challenged broilers with no additives had higher serum content of cholesterol $(P<0.0001)$, ALT, AST, and albumen $(P<0.05)$. There were not significant differences between control fed broilers and those fed salinomycin, $0.5 \%$ and $1 \%$ peppermint supplemented diets in the studied serum biochemical parameters $(P>0.05)$. Under Eimeria challenge conditions, the only $0.5 \%$ peppermint decreased serum content of cholesterol and ALT however both peppermint concentrations lowered AST content of serum compared to positive controls $(P<0.05)$, however, non-challenged treatments of broilers were not significantly different. The current study showed that Eimeria challenge significantly affected broilers' serum biochemical parameters like cholesterol, AST, ALT, and albumen. Similarly, Hirani et al., (19) found an increase in the serum level of cholesterol and serum AST and ALT activities 
in coccidian challenged broilers. However Mondal et al., (27) showed that Eimeria challenged broilers' plasma level of ALT and albumen were significantly decreased. The observed increase in serum cholesterol concentration of coccidian challenged broiler' in the current study might be due to impairment in liver which will lead to disturbed fat metabolism resulted from damaged intestinal epithelium in coccidiosis (9). In addition the significant increase in the serum AST and ALT activity in challenged broilers in the present experiment could be due to the injured liver and intestine (19) or it might be due to degeneration of cell membrane and tissues (28).

\section{CONCLUSION}

The current study was succeeded in performing the coccidiosis challenge model. It demonstrated that peppermint was similar to anticoccidial in controlling performance declining of broilers represented by WG and FCR. It was also as efficient as anticoccidial in improving of intestine

Table 9. Effect of different treatments on serum biochemical parameters of broilers at d 24 of age.

\begin{tabular}{|c|c|c|c|c|c|c|}
\hline Treatments* & $\begin{array}{c}\text { Cholesterol } \\
\text { (mg/dl) }\end{array}$ & ALT (ul) & AST (ul) & $\begin{array}{c}\text { Total } \\
\text { Protein } \\
\text { (g/dl) }\end{array}$ & $\begin{array}{l}\text { Albumen } \\
\text { (g/dl) }\end{array}$ & $\begin{array}{l}\text { Globulin } \\
\text { (g/dl) }\end{array}$ \\
\hline Negative control & $91^{\text {cd }}$ & $2.43^{\text {cd }}$ & $158^{\mathrm{c}}$ & 2.533 & 1.058 & 1.475 \\
\hline NC Salinomycin & $86^{\mathrm{d}}$ & $2.30^{\text {cd }}$ & $136^{\mathrm{c}}$ & 1.795 & 0.710 & 1.085 \\
\hline NC $0.5 \%$ peppermint & $\mathbf{8 5}^{\mathrm{d}}$ & $2.13^{\mathrm{d}}$ & $143^{\mathrm{c}}$ & 2.590 & 0.948 & 1.643 \\
\hline NC $1 \%$ peppermint & $94^{\text {cd }}$ & $2.90^{\mathrm{bcd}}$ & $157^{\mathrm{c}}$ & 2.333 & 0.948 & 1.385 \\
\hline Positive control & $141^{\mathrm{a}}$ & $4.70^{\mathrm{a}}$ & $244^{a}$ & 2.350 & 1.015 & 1.335 \\
\hline C Salinomycin & $120^{a b}$ & $3.80^{\mathrm{ab}}$ & $213^{a b}$ & 2.573 & 1.065 & 1.508 \\
\hline C $0.5 \%$ peppermint & $113^{b c}$ & $3.28^{\mathrm{bcd}}$ & $185^{\mathrm{bc}}$ & 2.470 & 1.048 & 1.423 \\
\hline C $1 \%$ peppermint & $124^{\mathrm{ab}}$ & $3.53^{\mathrm{abc}}$ & $182^{\mathrm{bc}}$ & 2.508 & 1.050 & 1.458 \\
\hline Pooled SEM & 4.247 & 0.194 & 8.119 & 0.071 & 0.031 & 0.046 \\
\hline \multicolumn{7}{|l|}{ Main effects } \\
\hline \multicolumn{7}{|l|}{ Challenge } \\
\hline None & $\mathbf{8 8}^{\mathbf{b}}$ & $2.44^{b}$ & $145^{b}$ & 2.239 & $0.868^{b}$ & 1.371 \\
\hline Eimeria & $119^{\mathrm{a}}$ & $3.53^{\mathrm{a}}$ & $193^{\mathrm{a}}$ & 2.517 & $1.054^{\mathrm{a}}$ & 1.463 \\
\hline \multicolumn{7}{|l|}{ Additive } \\
\hline Control & 116 & 3.56 & 201 & 2.441 & 1.036 & 1.405 \\
\hline Salinomycin & 103 & 3.05 & 174 & 2.184 & 0.888 & 1.296 \\
\hline $0.5 \%$ Peppermint & 99 & 2.70 & 164 & 2.530 & 0.998 & 1.533 \\
\hline $1 \%$ Peppermint & 109 & 3.21 & 170 & 2.420 & 0.999 & 1.421 \\
\hline \multicolumn{7}{|l|}{$\mathbf{P}>\mathbf{F}$} \\
\hline Challenge & $<.0001$ & 0.0026 & 0.0011 & 0.0919 & 0.0053 & 0.4193 \\
\hline Additive & 0.5131 & 0.4823 & 0.3854 & 0.3729 & 0.3851 & 0.3678 \\
\hline Challenge $x$ additive & 0.0001 & 0.0022 & 0.0018 & 0.0900 & 0.0577 & 0.1401 \\
\hline
\end{tabular}

a, b, c, d - Means within the same column with different superscripts differ significantly at $(\mathrm{P}<0.05)$. ALT= Alanine transaminase, and AST = Aspartate aminotransferase (AST). "See Table 3 for details of treatments. integrity by increasing villus height and Mahmod who helped me in field and VH:CD ratio and decreasing crypt depth in laboratory works. I also thank Department of Eimeria challenged broilers. These findings Animal Production, and Animal project at suggest that peppermint can be a promising preventative alternative to anticoccidial for reducing of coccidiosis acuteness.

\section{ACKNOWLEDGEMENTS}

I hereby thank my colleagues Dr. Shawkat M'Sadeq, Dr, Sleman Beski, and Mr. Avraz college of Agricultural Engineering Sciences, University of Duhok for their help and support.

\section{REFERENCES}

1. Abbas, R. Z., Z. Iqbal, Z.U. Sindhu, M.N. Khan, and M. Arshad. 2008. Identification of 
Cross-Resistance and Multiple Resistances in Eimeria tenella Field Isolates to Commonly Used Anticoccidials in Pakistan. J. Appl. Poult. Res. 17: 361-368. DOI:10.3382/japr.2008-00027

2. Abdel-Wareth, A. A. A., S. Kehraus, and KH. Südekum. 2019. Peppermint and its respective active component in diets of broiler chickens: growth performance, viability, economics, meat physicochemical properties, and carcass characteristics. Poult. Sci. 98: 3850-3859

3. Abdullah, L. N., and L. T. O. Al-Barwary. 2020. Effect of Artemisia splendens powder and extract on broiler chicken's performance, lymphoid organ weight, gut morphology and serum biochemicals during coccidiosis challenge. Iraqi J. Agric. Sci. 51(2): 611-618

4. Aguanta, B. N., L. A. Fuller, M. C. Milfort, S. M. Williams, R. Rekaya, and S. E. Aggrey. 2018. Histologic Effects of Concurrent Heat Stress and Coccidial Infection on the Lymphoid Tissues of Broiler Chickens. Avian Dis. 62: 345-350

5. Allen, P. C., J. Lydon, and H. D. Danforth. 1997. Effects of components of Artemisia annua on coccidia infections in chickens. Poult. Sci. 76(8): 1156-1163

6. Anderson, W. I., J. J. Giambrone, O. J. Fletcher Jr, C. S. Eidson, and W. M. Reid. 1976. Demonstration of Eimeria tenella in the bursa of Fabricius of chickens. Avian Dis. 20: 752-755

7. Asadi, N., S. D. Husseini, M-T. Tohidian, N. Abdali, A. Mimandipoure, M. RafieianKopaei, and M. Bahmani. 2017. Performance of broilers supplemented with peppermint (Mentha piperita L.) powder. Evid. Based Complement. Alternat. Med. 22(4):703-706

8. Barbour, E. K., R. R. Bragg, G. Karrouf, A. Iyer, E. Azhar, S. Harakeh, and T. Kumosani. 2015. Control of eight predominant Eimeria spp. involved in economic coccidiosis of broiler chicken by a chemically characterized essential oil. J. Appl. Microbiol. 118(3): 58391

9. Basith, S. A., G. Rajavelu, and B. M. Manohar.2000. Biochemical studies in experimental Eimeria necatrix infection in chickens. Indian Vet. J. 75(10): 876-878

10. Brito, L. D. S., E. N. Pereira, A. A. da Silva, V. B. C. Silva and F. L. da C. Freitas.
2014. Experimental infection with sporulated oocysts of Eimeria maxima (Apicomplexa: Eimeriidae) in broiler. J. Vet. Med. 283029. DOI: $10.1155 / 2014 / 283029$

11. Chapman, H. D., and T. K., Jeffers. 2014. Vaccination of chickens against coccidiosis ameliorates drug resistance in commercial poultry production. Int. J. Parasitol. Drugs Drug Resist. 4:214-217

12. Dalloul, R. A., and H. S. Lillehoj. 2006. Poultry coccidiosis: recent advancements in control measures and vaccine development. Expert Rev. Vaccines. 5: 143-63

13. Evans, J. W., M. S. Plunkett, and M. J. Banfield. 2001. Effect of an essential oil blend on coccidiosis in broiler chicks. Poult. Sci. 80 (suppl. 1): 258 (Abstract).

14. Frankič, T., M. Voljč, J. Salobir, and V. Rezar. 2009. Use of herbs and spices and their extracts in animal nutrition. Acta agric. Slov. 94(2): 95-102

15. Guo, F.C., B. A. Williams, R. P. Kwakkel, H. S. Li, X. P. Li, J. Y. Luo, W. K. Li, and M. W. A. Verstegen. 2004. Effects of mushroom and herb polysaccharides, as alternatives for an antibiotic, on the cecal microbial ecosystem in broiler chickens. Poult. Sci. 83(2): 175-182 16. Hasan, H. I., and S. A. M'Sadeq. 2020. Effect of peppermint supplementation as powder or extract on broiler performance, serum biochemical content and gut health under E. coli challenge. Iraqi J. Agric. Sci. 51(1): 299-310.

17. Hashemi, S. R., and H. Davoodi. 2011. Herbal plants and their derivatives as growth and health promoters in animal nutrition. Vet. Res. Commun. 35(3): 169-180

18. Helal, I. B., S. N. Ahmed, S. E. Amer, and R. E. El-Shershaby. 2019. Histopathological studies on experimentally Eimeria tenellainfected broiler chicken. Egypt. J. Exp. Biol. (Zoo.). 151(1): 25-34

19. Hirani, N. D., J. J. Hasnani, S. S. Pandya, and S. P. Madhira. 2018. Biochemical changes in induced caecal coccidiosis in broiler birds given different feed anticoccidials at anand, Gujarat, India. Int. J. Curr. Microbiol. Appl. Sci. 7(07): 10441051

20. Huff, W. E., and M. D. Ruff. 1982. Eimeria acervulina and Eimeria tenella 
Infections in Ochratoxin A-Compromised Broiler Chickens. Poult. Sci. 61: 685-692

21. Iji, P. A., A. Saki, and D. R. Tivey. 2001. Body and intestinal growth of broiler chicks on a commercial starter diet. 1. Intestinal weight and mucosal development. Br. Poult. Sci. 42: 505-13.

22. Ilić, T., M. Knežević, S. Aleksiékovačević, V. Nešić, and S. Dimitrijević. 2004. Immunohischemcal investigation of the bursa of Fabricius in chickens experimentally infected by Eimeria tenella. Acta Vet.Beograd. 54: 411-417

23. Lee, K-W., H. Everts, H. Kappert, M. Frehner, R. Losa, and A.C. Beynen. 2003. Effects of dietary essential oil components on growth performance, digestive enzymes and lipid metabolism in female broiler chickens. Br. Poult. Sci. 44: 450-7

24. Maxey, B. W., and R. K. Page. 1977. Efficacy of lincomycin feed medication for the control of necrotic enteritis in broiler-type chickens. Poult. Sci. 56: 1909-13

25. McDougald, L. R., and J. Hu. 2001. Blackhead disease (Histomonas meleagridis) aggravated in broiler chickens by concurrent infection with caecal coccidiosis (Eimeria tenella). Avian Dis. 45: 307-12

26. Mehri, M., V. Sabaghi, and F. Bagherzadeh-Kasmani. 2015. Mentha piperita (peppermint) in growing Japanese quails' diet: serum biochemistry, meat quality, humoral immunity. Anim. Feed Sci. Technol. 206: 5766

27. Mondal, D. K., S. Chattopadhyay, S. Batabyal, A. K. Bera, and K. Bhattacharya. 2011. Plasma biochemical indices at various stages of infection with a field isolate of Eimeria tenella in broiler chicken. Vet. World. 4(9): 404-409.

28. Montgomery, R., T. W. Conway, and A. A. Spector. 1990. Biochemistry: A Case Oriented Approach. $5^{\text {th }}$ ed. The S.C.V. Mosby Co. St. Louis, USA

29. M'Sadeq S. A. 2019. Effect of dietary supplementation of miaclost on performance and gut morphology in broiler chickens challenged with Escherichia coli. Iraqi J. Agric. Sci. 50(2):506-514.

30. M'Sadeq, S. A., S-B. Wu, M. Choct, R. Forder and R.A. Swick. 2015. Use of yeast cell wall extract as a tool to reduce the impact of necrotic enteritis in broilers. Poult. Sci. 94(5): 898-905

31. Muthamilselvan, T., K. Tien-Fen, W. Yueh-Chen, and Y. Wen-Chin. 2016. Herbal remedies for coccidiosis control: a review of plants, compounds, and anticoccidial actions. Evid. Based Complementary Altern. Med. 119

32. Nameghi, A. H., O. Edalatian, and R. Bakhshalinejad. 2019. Effects of a blend of thyme, peppermint and eucalyptus essential oils on growth performance, serum lipid and hepatic enzyme indices, immune response and ileal morphology and microflora in broilers. J. Anim. Physiol. Anim. Nutr. 00: 1-11

33. Ocak, N., G. Erener, A.K.F. Burak, M. Sungu, A. Altop, and A. Ozmen. 2008. Performance of broilers fed diets supplemented with dry peppermint (Mentha piperita L.) or thyme (Thymus vulgaris L.) leaves as growth promoter source. Czech J. Anim. Sci. 53(4): 169-175

34. Oláh, I. N. Nagy, and L. Vervelde. 2014. Structure of the Avian Lymphoid System. In Avian Immunology. $2^{\text {nd }}$ ed. pp. 11-44 (Schat, K.A. B. Kaspers, and P. Kaiser. Eds.). Academic Press, Boston, USA

35. Pasqua, R. D., N. Hoskins, G. Betts, and G. Mauriello. 2006. Changes in membrane fatty acids composition of microbial cells induced by addiction of thymol, carvacrol, limonene, cinnamaldehyde, and eugenol in the growing media. J. Agric. Food Chem. 54: 2745-2749

36. Quiroz-Castañeda, R. E. and E. DantánGonzález. 2015. Control of Avian Coccidiosis: Future and Present Natural Alternatives. BioMed Res. Int. 2015: 1-11. DOI:http://dx.doi.org/10.1155/2015/430610

37. Schuhmacher, A., J. Reichling, and P. Schnitzler. 2003. Virucidal effect of peppermint oil on the enveloped viruses herpes simplex virus type 1 and type 2 in vitro. Phytomedicine. 10(6-7): 504-510

38. Tassou, C., K. Koutsoumanis, and G.-J.E. Nychas. 2000. Inhibition of Salmonella enteritidis and Staphylococcus aureus in nutrient broth by mint essential oil. Food Res. Int. 33(3-4): 273-280

39. Tyzzer, E. E. 1932. Criteria and methods in the investigation of avian coccidiosis. Science. 75 (1943): 324-328 
40. Williams, P. 2001. The use of essential oils and their compounds in poultry nutrition. World Poult. 17(4): 14-15

41. Williams, R. B. 2005. Intercurrent coccidiosis and necrotic enteritis of chickens: Rational, integrated disease management by maintenance of gut integrity. Avian Pathol. 34: $159-180$
42. Windisch, W. K., C. Schedle, Plitzner, and A. Kroismayer. 2008. Use of phytogenic products as feed additives for swine and poultry. J. Anim. Sci. 86: E140-E148

43. Youn, H. J. and J.W. Noh. 2001. Screening of the anticoccidial effects of herb extracts against Eimeria tenella. Vet. Parasitol. 96(4): 257-263. 